\title{
Mediating colonial marginality and (minor) ity in Isabel de Guevara's Carta a la Princesa Doña Juana
}

\author{
Mediando a marginalidade colonial e a (menor) idade \\ na Carta a la Pincesa Doña Juana de Isabel de Guevara
}

Mediando la marginalidad colonial y la (poca) edad en la Carta a la Princesa Doña Juana de Isabel de Guevara

\author{
Raúl Marrero-Fente* \\ Scott Ehrenburg**
}

\begin{abstract}
Written in 1556 by one of the participants in the conquest and colonization of the River Plate, Isabel de Guevara's letter to the princess Juana is a critical testimony of the time. The value of this document arises from the author's personal condition, defined as eyewitness of the described facts. It is in this way that it establishes the verisimilitude of the narration based on juridical speech. This article seeks to interrogate the binary constructions of colonial/imperial, margin/center, and local/global, upon an examination of Isabel de Guevara's letter in a broader Spanish American colonial context.
\end{abstract}

Keywords: Isabel de Guevara; female epistolography; female conquistador; conquest of America; minority discourse

Resumo: Escrito em 1556 por um dos participantes da conquista e colonização do Rio da Prata, a carta de Isabel de Guevara para a princesa Juana é um testemunho crucial de seu tempo. O valor desse documento vem da condição pessoal do autor, definida como testemunha ocular dos fatos descritos. É dessa maneira que ela estabelece a verossimilitude da narração baseada no discurso jurídico. Esse artigo busca interrogar as construções binarias de colonial/imperial, margem/centro e local/global, a partir de um exame da carta de Isabel de Guevara em um contexto hispano-americano mais amplo. Palavras-chave: Isabel de Guevara; epistolografia feminina; conquistador feminina; conquista da América; discurso minoritário (ou de minorias)

\footnotetext{
* Professor of Spanish and Law at the University of Minnesota.<rmarrero@umn.edu>

**Ph.D. Candidate in Spanish Literature at the University of Minnesota. <ehren020@umn.edu>

$<$ biographic data/dados biográficos/>
} 
Resumen: Escrita en 1556 por uno de los participantes de la conquista y colonización del Río de la Plata, la carta de Isabel Guevara a la princesa Juana es un testimonio crucial de su tiempo. El valor de este documento proviene de la condición personal del autor, que se define como un testigo ocular de los hechos descritos. Esto es lo que establece la verosimilitud de la historia basada en el discurso jurídico. Este artículo tiene por objeto examinar las construcciones binarias de colonial/imperial, margen/ centro y local/global, a partir del examen de la carta de Isabel Guevara en un contexto más amplio hispanoamericana.

Palabras clave: Isabel de Guevara; epistolografía femenina; conquistador femenina; la conquista de la América; el discurso minoritario (ou de las minorías)

Feminist studies and women's literature have found themselves in a tenuous position - characterized by both marginality and an access point to alternative ways of "knowing" in patriarchal discourse. It is precisely in this space of thought, in determinate historical moments, where agency is both gained and affirmed. In tracing back women's studies, specifically in a literary tradition, women's subjugation is clear, as well as that of other minorities. The inaccessibility to formal education, economic constraints, and overarching social practices conditioned their subjugation. This effort to silence women by limiting access to textual production and deeming what little scholarship they produced as having little importance is quite apparent in the construction of a colonial subjectivity.

Until recently, these invisibilities have been present not just in a vast tradition of women's literature but more acutely manifested in a complete discipline of literary studies ${ }^{1}$. In the scope of subfields of specialization in the US academy, colonial studies are quite new relative to its counterparts, like for example, literary studies focused in the contemporary era. The (re)discovery of texts have proven fruitful in our current theorizations about coloniality, empire, mercantilism, and commodity. The presence of women's texts in the colonial Latin America period is very limited in its range ${ }^{2}$. In many anthologies, the same authors and the same texts have been constructed, deconstructed, and refashioned so as to uncover specific epistemological underpinnings of a certain "double" minority position as women in the "new world" context of the Americas. Moreover, the colonial condition incorporates

\footnotetext{
1 Restall calls Isabel de Guevara "invisible conquistador" (RESTALL, 2003, p. 172).

2 By no means should this point be understood as an indication that texts by women don't exist. What is clear is the dearth of scholarship that exists regarding texts produced by not just Spanish American women but also other minorities like indigenous groups, gypsies, and the enslaved.
} 
certain strategies (discursive and rhetorical) to construct a certain corpus of identity characteristics indicative of a colonial subjectivity. However, in our discussion we seek to interrogate the binary constructions of colonial/imperial, margin/center, and local/global because, upon an examination of Isabel de Guevara's letter in a broader Spanish American colonial context, it is clear that the strategies she employs are in step with minority literature more so than exclusively women's literature. As we will demonstrate, critics have failed to escape the trap of essentializing women's writing or monolithically reading the "woman's voice" as it pertains to a specific socio-historical context (colonial) and thus misreading Guevara's contribution to our understanding of colonial literature. It is precisely through this in-between or more liminal space that demonstrates what Cherrie Moraga and Gloria Anzaldúa can argue as a mestizaje of linguistic form/strategy, a 16th century prototype for later theorizations. This liminal "space" will be the point of departure for this essay as we focus on the internal ambiguities and contradictions present in the text.

Isabel de Guevara speaks of a lost women's literary tradition precisely due to the scarcity of biographical information about her. Guevara was apart of a collective of Spaniards that set sail from Cádiz in 1534 under the direction of Pedro de Mendoza, a wealthy nobleman who would be the leader of the expedition to La Plata and Paraguay. Once ashore, the settlers struggled through disease, famine, and skirmishes with natives, and not surprisingly left many dead (SCOTT, 1999, p. 4-5; LOPRETO, 1976, p. 14-17). Mendoza would eventually fall victim like many of his colonial contemporaries to a venereal disease, singularly syphilis. Due to his condition, Mendoza left to return to Spain and ultimately ended up dying on the seas of the Atlantic during his journey. Captain Juan de Ayolas quickly replaced Mendoza, and he directed the colony to move to present day Asunción and hence was named as the founder of present-day Paraguay (SCOTT, 1999, p. 4-5).

Isabel de Guevara was born in Spain. The precise date and place of her birth, however, is unknown. Despite such limited biographical information, it is generally assumed that she died in the New World, probably in the region of Río de la Plata in the late 16th century. Guevara arrived in the Americas in 1536 as a member of the expedition of Pedro de Mendoza and later on wrote a letter to Princess Juana on July 2, 1556. The original letter can be found in the National Archive in Madrid and was published in 1877 by Justo Zaragoza (1974). This letter, written by Isabel de Guevara, is the first-known text to recount 
the conquest and colonization of the Río de la Plata region from a female point of view as well as one of the first critical testimonies of those processes. The missive questions the imposed social norms placed on women establishes a precedent of targeting a female audience (particularly women who hold power-Princess Juana, specifically) in order for her voice to be heard, and challenges the limits imposed by social conventions on female epistolary literature. This tradition of female letter writing was normally confined to personal or family issues, with only a few exceptions that related to matters of the public sphere (CHEREWATUK \& WIETHAUS, 1993, p. 8-9; COUCHMAN \& CRABB, 2005, p. 3-20; DAYBELL, 2001). Perhaps upon realizing a sense of female agency and control of discourse, Isabel de Guevara allies herself with Princess Juana and consequently transgresses social codes and topics that would otherwise be forbidden to women. This alliance aims to establish a female authority and thus raises a reading of the text that distinguishes it from similar letters written by men. The letter by Isabel de Guevara presents a group of women that endures with men the trials and tribulations of the New World; however, it is only the women who assume the role of savior. This letter distinguishes itself from other chronicles of the Americas in its articulation of the participation of women in the colonial enterprise ${ }^{3}$.

It is worth asking why Isabel de Guevara wrote her letter twenty years after the events described. One possible answer lies in the power relations prevailing during the administration of Domingo Martínez de Irala, who was appointed in 1555 the governor of the territories of the Río de la Plata and was granted permission to distribute land (ZARAGOZA, 1974, p 797). On May 14, 1556 Martínez de Irala enacted the Ordinances (Ordenanzas), which distributed twenty thousand natives to three hundred colonizer (ZORRAQUÍN BECÚ, 1988, p. 132- 133). Just weeks after the publication of the Ordinances, on July 2, 1556, Isabel de Guevara wrote her letter. By placing the missive of Isabel de Guevara in this historical context, we see it taking on a legal nature that not only defies the laws of Governor Martínez de Irala, but is intended to be, in itself, a legal document. Above all, however, it is primarily a demand for women's rights, specifically a woman colonizer's rights.

\footnotetext{
3 For recent studies on Isabel de Guevara's letter see Mar del Langa, "Mujeres en la expedición de Pedro de Mendoza: cartas, crónicas y novelas; verdades, mentiras, ficciones y silencios." América sin nombre, 15, 2010, p. 15-29; and Rocío Quispe-Agnoli, "Discursos coloniales escritos y agencia femenina: La 'Carta a la Princesa Juana' de Isabel de Guevara", CIEHL: Cuadernos Internacional de Estudios Humanisticos y Literatura, 5, 2005-2006, p. 81-91.
} 
Isabel de Guevara made her request for rights based on an argument supported by facts to convince readers of the truth of her story. According to legal rhetoric, this is a necessity in order to understand the case (the facts) and justify it. This is precisely what distinguishes the letter from others: Guevara establishes the relationship between the facts and the law through rhetoric. This process has two moments of truth. The first, describe their involvement in colonization. The second, challenge the arguments of the other party. In this case, the party is not an individual, but the Crown." In our opinion, here lies the most novel aspect of the claim because the author appeals directly to the Crown, not local authorities. The letter by Isabel de Guevara is a defense of the rights of women as she questions the place assigned to her and her contemporaries by the patriarchal society of that time.

The value of the letter from Isabel de Guevara to Princess Juana comes from the personal status of the author, who describes herself as an eyewitness of the events listed. This establishes the plausibility of the narrative from legal discourse. Formally, the letter follows the models of ars epistolandi with the novelty of transgressing the representation of woman because it appears as a public subject seeking to demand both rights and property from royal authority.

The crucial role of rhetoric and law in the early modern period allows for the exploration of the relationships between these two forms of knowledge and its influence on literature. So, for example, the evolution of legal rhetoric as an important means of expression in the European legal culture, particularly in a Spanish context, is rooted in the rhetorical schools of the classical era. Moreover, the legal system in Spain comes from the tradition of classical Roman law. The idea of a common origin of rhetorical and legal models is important for understanding its evolution in institutions and legal functions as well as its relationship with literature. This process began in the Middle Ages at the University of Bologna in Italy, where the relationship between rhetoric and the law led to the emergence of new tasks such as drafting contracts by notaries and, more importantly, the construction and maintenance of document archives. Furthermore, it was common that lawyers write technical advice to notaries in their work and that instructors of ars notaria also taught law (SEIGEL, 1968, p. 69).

In Spain, during the early modern period, this relationship between legal and rhetorical studies resulted in the decline of orators in the legal process and their replacement by lawyers specializing in technical matters. This circumstance was also due to changes in the state and 
the rise of legal production, which was manifested in the large number of laws and regulations issued. Some of the most important are Siete partidas (1263), the Ordinance of Alcalá de Henares (1356), Laws of Toro (1505), and the New Compilation of the Laws of Castile (1567). It was also the predominance of a written culture that necessitated a call for contracts in business and commercial enterprises. It is not a coincidence that in the history of legal documents letters appear redacted according to a formal structure, serving as a starting point for the production of later manuals with formulaic approaches to letter writing style. According to Costamagna, this traditiocartae began in the eleventh century (COSTAMAGNA, 1970, p. 34-95). The basis for these changes is reflected in the transition from classical rhetoric to more practical issues during the medieval epoch in Italy, and was expressed in the letter-writing manuals called ars dictaminis (which showed examples of letters for different occasions), and the ars notaria, notaries manuals containing formulas to draft contracts and other legal documents. The most important element in this process is the presence of drafting provisions in the ars notaria and notarial formulas in the ars dictaminis (SEIGEL, 1968, p. 206). These common features between the ars notaria and the ars dictaminis also appeared in Spain.

This is another act that explains the abandonment of oral and theatrical tradition of public speaking and confirms the close relationship between the epistolography and law. Ars dictaminis, manuals, and collections of letters - called dictamina - began to appear in legal documents, especially in the ars notaria (MURPHY, 1989, p. 77). Although different authors consider the structure of the letter according to the models of the ars dictaminis coming from prayer in classical rhetoric, this classification is related to the medieval era. The appearance of the ars epistolandi, replacing the ars dictamindi, caused a change in the structure of the letters, especially in separating the salutatio from the exordium, coupled with other changes in punctuation and internal division of the letters (KRISTELLER, 1983, p. 1-19).

In the context of Colonial Latin American literature this transit of the ars dictandi to the ars epistolandi is an essential element in the evaluation of the epistolary genre. By epistolary genre we define the letters that were written in the Americas, and include ones related to the courts, cartas de relaciones and correspondence about personal issues (MARRERO-FENTE, 1999, p. 96). In Colonial Latin America, the immediate antecedents of the epistolary genre are the cartas de relación of Christopher Columbus and Hernán Cortés. There is a close 
relationship between the discourses of epistolography and law during the colonial period because the letters used legal elements throughout the text. In this sense it is necessary to recall the manuals regarding letter writing and the law appearing in Spain, such as Gaspar de Texeda's, Este estilo de esrebir cartas mensageras (1549), Antonio Torquemada, Manual de escribentes (1552), Gabriel de la Gasca, Manual de avisos del perfecto cortesano (1631), Juan Luis Vives, De conscribendis epistolis (1536). While the presence of rhetoric is important, it is in the epistolary doctrine where one should study missive production in colonial period. Another key element is sacred oratory, and especially, Christian epistolary tradition, particularly the models of Pauline Epistles (DOTY, 1973, p. 21-42). The latter played a crucial role, especially in women's epistolography, as they were the models that were available to women and appeared in religious literature, especially the Bible.

The rhetorical devices found in the letter by Guevara, respond to the letter's recipient; a decisive element for the petition of rights that are manifested in two dimensions. First, explicitly in the demand for a repartimiento, the author closely follows the basic principles of the judicial process: presentation of the facts, denouncing injustice or violation of rights, and appeal for justice. Second, although implicitly, the letter exceeds the mere petition for a parcel of land and becomes a defense of the rights of women criticizing the legal system of the time through the direct link established with royal authority and, thus, transgresses the social role for women at the time. Since the beginning of the conquest of America land claims were coded through different laws up until Recopilación de las leyes de los Reynos de las Indias in 1680 .

In the letter the author assumes the role of eye-witness of the facts she recounts giving credibility to her writing from legal discourse (FOUCAULT, 1992, p. 11-88). The letter provides access to the Royal Palace, where her testimony will be exposed, surpassing the viceregal audience, an area in which the female voice is subordinated to the patriarchal figure of Governor Martínez de Irala. The eyewitness formula on which rests her argument is part of a tradition that appears from the letters of Columbus and Cortes. Precisely were the descriptions of eyewitnesses that helped create the image of the New World, transforming European historiography. The letter by Isabel de Guevara is an example of the new narrative forms that arise as a result of the change in the ars epistolandi and in the early modern epistolography. The appearance of the ars epistolandi, replacing the ars dictandi transformed 
the structure of the letters, in particular separated the salutatio from the exordium, and changed the punctuation and the internal division (KRISTELLER, 1983, p. 8).

The letter of Isabel de Guevara is written on the model of the ars epsitolandi: greeting, exordium, narration, petition, and conclusion. Beginning with the greeting, Guevara employs a humble and respectful tone, while using a direct style. The author and the addressee of the letter are women; hence the locus of enunciation acquires a different meaning from the letters written by men, who followed strict protocols of courtesy when speaking to the royal authorities. In the text are various levels of complaint to reach out and gain the trust of the princess Juana.

Isabel de Guevara's letter pushes the limits of social conventions in female epistles. This tradition limited women's letters to personal or family issues and, quite rarely, to matters of the public sphere. Isabel de Guevara seeks the complicity of Princess Juana, to sidestep the discursive control around women, transgressing the codes of the topics forbidden to women in the letter writing. First, this difference stems from the fact that the royal family member is a princess and not a prince. The result is that, in the presence of a female authority, all the conventions of a court, traditionally conceived from a male point of view, are modified. Moreover, the demand for rights comes from a woman who relates the adventures and dangers she and other women endured to save their male comrades. Finally, Isabel de Guevara does not just ask for rewards for herself, but for her husband as well.

Isabel de Guevara attempts to influence Princess Juana through a meta-textual comment on the history of the chroniclers of the conquest of America, however, her view is revealed indirectly by means of comparisons and examples articulated through analogies to the central thesis of the letter: the prominence of women in the exploration and conquest of the territories of the Río de la Plata area. Isabel de Guevara's text questions power relations because on more than one occasion she regrets having been excluded from the repartimientos. Thus, the commentary found in the letter appears as a space to complete the story that male chroniclers fail to tell. It is a palimpsest over other historiographical texts, and it opens a different version of the story that had before been censored. Such revision of colonial discourse implies a criticism of the binary representation of gender, a trend that is reflected in colonial historiography, to award women subordinate roles, or simply to erase the female figures from episodes of the conquest (MARREROFENTE, 1996, p. 1-7). 
Isabel de Guevara interrupts these silences by making the female the protagonist of the historical process. That is to say, in the letter the female gender becomes a category of analysis. The immediate consequence of this rhetorical strategy is the construction of a new colonizing subject, since it incorporates for the first time female gender in colonial discourse. Isabel de Guevara appears as a public subject that appeals to an absent authority (also female), through an act of legitimation based on her knowledge of the events described. Another important element is the link between the petitioner (woman) and the State (woman) is recreated in a female writer who writes a report about the life of Spanish women during the colonization of the Río de la Plata. The author builds her request through her own participation in the conquest. Therefore, the letter by Isabel de Guevara is an official document addressed to a royal authority, requesting payment for services rendered. The organization of the request is persuasive in tone with words chosen in order to highlight the sacrifices of women at the behest of the Crown.

The metaphor of hunger is the center of a complex rhetorical game. First, it raises the virtue of the author for the work endured. Second, the rhetoric of the letter is organized around the hunger for power and wealth which functions as the motives for the behavior of Isabel de Guevara. It should be clear that the ambition for wealth and power also appear in men and are described in the letter ironically. Another significant moment in the text is the reference to religious authority as a source of legitimacy of the narrative, through the example of hunger in Jerusalem. This example allows for a brief discuss the influence of the epistolary tradition of Christianity, especially the Pauline epistles. St. Paul's letters were important for female epistolography models because they were better known by women. The ironic tone of the hunger metaphor serves to challenge existing power relations at the time, while working as a trope that primes the narration. The technique of erasing rhetorical conventions through visual images, such as description of hunger, is a similar technique to what appears in the Pauline letters.

The purpose of the narrative is to instruct the reader, and in order to do so Isabel de Guevara builds a story that explains the work of women. The presence of sentimental memories correlate to the development of an argument, by acting as a device that creates an external narrative event (GOLDSMITH, 1989,p. 69). The letter features a collective of women who share the work and dangers right along side men, however, it is women who assume the role of savior, and their participation in 
the colonial enterprise which this letter highlights is absent in other chronicles. The author supports her request through religious discourse and warns that women's actions are an act of Christian charity. The image of the selfless woman who sacrificed herself for men found in this letter situates it in the larger tradition of Christian epistolography and ars praedicandi, and works as a deterrent technique. The representation of women as victims in the women's letter writing is an old tradition from Ovid, but in this case what is important is that women's suffering is justified by way of Christian charity. Isabel de Guevara's letter is a veiled complaint regarding the chivalric codes of the conquerors: honor, courage and tenacity. The letter contradicts the official version of history presented by male chroniclers on an ethic of service, sacrifice and honor.

Although the purpose of the letter of Isabel de Guevara is to demand payment for her services and sacrifice, it is also a petition for an injunction of the law that creates a stumbling block for her (Martínez de Irala's laws), which did not recognize the rights of women to receive encomiendas. During the colonial period women's right to own lands became a controversial topic which is clearly reflected as a central issue in the letter. This letter was entrenched in the debate but stood out by the transgressive way the text tries to make a pact with the state. To be clear, the letter is addressed to Princess Juana, hence the letter is mediated through its legal function for a demand for certain rights. Moreover, Isabel de Guevara aspires to enter into dialogue with power through writing. In the letter the author's ego appears only a few times, unlike the letters of male writers. The confidential tone of the author recounting the work of women is an action similar to that employed by the picaro faced with the authorities in court. The letter from Isabel de Guevara oscillates between public and private, revealing the conflict between the public self that aspires to have greater social independence, and a private self-facing the constraints of marriage. (OTS Y CAPDEQUÍ, 1969, p. 214-219). In the conclusions of the letter, the author insists on her request but included the name of her husband. The mention of her husband has an ironic tone because the author shares with men the desire to have encomiendas and slaves.

Isabel de Guevara made the request for rights based on an argument supported by the facts to convince Princess Juana of the truth of her story. According to legal rhetoric, it is vital to recount the facts in order to understand the case and have justice served. This is precisely what distinguishes the Guevara's letter from others in general because it 
establishes the relationship between the facts and the law through rhetoric. This truth building process has two salient moments. The first to describe her participation in the conquest and, second, when challenging the arguments of the other party, which in this case is not any individual, but governor Martínez de Irala. This is the most innovative aspect of the claim, because the author appeals directly to the figure of the royal authority, and not to local authorities.

We have argued until now - through a privileging of the confluence of the law and rhetoric - that Guevara's letter puts into question in part the tenets of gender roles. However, what does the letter offer in the way of a colonial reality and a writing style characterized by a colonial subjectivity? Undoubtedly, Guevara textually demands indemnification, but once socio-historically contextualized, these claims were not unheard of for the time period. As we have suggested the presence of women's text in the colonial period is very limited in its range. What is more, the colonial condition incorporates certain strategies (discursive and rhetorical) to construct a certain corpus of identity characteristics indicative of a colonial subjectivity. However, upon closer interrogation of the binary constructions of colonial/imperial, margin/center, and local/global in relation to Isabel de Guevara's letter demonstrates that in a broader colonial context, the strategies she employs are in step with a "minor" literature.

Minor literature and discourse as explained by Yolanda MartínezSan Miguel, permits a reconceptualization of how one can frame colonial discourse and subjectivity. Her theorizations afford a positioning of Isabel de Guevara's work through her rhetorical and discursive strategies as categorically colonial. If the text is framed in relation to position instead of essence then a much clearer sense of her positionality is privileged as a subjugated subject (woman and additionally "colonial"). That is to say, the locus of enunciation becomes crucial to understand the space of her writing in an existing economic and political network. Martínez-San Miguel states "spatial conceptions assist in understanding the political setting of social and cultural experiences that take place outside and before the existence of modern national boundaries" (MARTÍNEZSAN MIGUEL, 2009, p. 166). According to Martínez-San Miguel, revisting insights by Deleuze and Guatari, are three characteristics that constitute a "minor" literature: deterritorialization of language, individual political dimension, and a collective enunciation. However, only upon the fusion of all three is what constitutes it as "revolutionary" quintessential colonial discursivity. 
Guevara employs the same linguistic tactics as her male counterparts-like Las Casas and Columbus-in order to describe a colonial reality otherwise inconceivable by the Spanish monarchs particularly through the strategies of aphasia and repetition. The first text below is a fragment from Diarios de viaje of Columbus that MartínezSan Miguel provides and the second quote is from Guevara's letter, both show similar intriguing qualities of aphasia:

Y vide muchos árboles muy disformes de los nuestros, d'ellos muchos que tenían los ramos de muchas maneras y todo en un pie, $\mathrm{y}$ un ramito es de una manera y otro de otra; $\mathrm{y}$ tan disforme, que es la mayor maravilla del mundo cuánta es la diversidad de la una manera de la otra. Verbigracia: un ramo tenía las fojas de manera de cañas y otro de manera de lentisco y así en un solo árbol de cinco o seis d'estas maneras, y todos tan diversos (MARTÍNEZ, 2009, p. 181)4.

... y como la armada llegase al puerto de Buenos Ayres, con mill é quinientos hombres, y les faltase el bastimento, fue tamaña la hambre, que, á cabo de tres meses, muyrieran los mill; esta hambre fue tamaña, que ni la de Xerusalen se le puede ygualar, ni con otra ninguna se puede conparar (SCOTT, 1999, p. 9).

In both texts we see the authors' struggle with a language that does not reach or capture the complexity of their testimony, a striking aphasia. Isabel de Guevara reaches the limits of language as her narration moves from describing a great hunger to later pronouncing a hunger that goes beyond that which was experienced in Jerusalem. Her use of ygualar and conparar speak in similar ways to Columbus's deployment of maravilla and disforme as empty signifiers (MARTÍNEZ-SAN MIGUEL, 2009, p. 181). It is clear from these two texts that Latin American (the Americas) reality spatially resignifies language to reflect a new discursive entity. This is also clear through another characteristic strategy by colonial "minor" literature, the use of repetition both linguistically and thematically.

Both authors present a control of a colonial reality by their employment of repetition in order to communicate an ideological

\footnotetext{
${ }^{4}$ I saw many trees very unlike those of our country. Many of them have their branches growing in different ways and all from one trunk, and one twig is one form, and another in a different shape, and so unlike that it is the greatest wonder in the world to see the great diversity; thus one branch has leaves like those of a cane, and others like those of a mastick tree: and on a single tree there are five or six different kinds.
} 


\section{message. The first text is an excerpt from Las Casas's Brevisima relación} de la destrucción de las Indias and the second Guevara's letter:

En estas ovejas mansas y de las ciudades susodichas por su Hacedor y Criador así dotadas, entraron los españoles desde luego que las conocieron como lobos y tigres y leones crudelísimos de muchos días hambrientos. Y otra cosa no han hecho de cuarenta años a esta parte, hasta hoy, y ho en día lo hacen sino despedazallas, matallas, angustiallas, afijillas, atormentallas, y destruillas por las estrañas y nuevas y varias y nunca otras tales ni leídas ni oídas maneras de crueldad, de las cuales algunas pocas debajo se dirán, en tanto grado que habiendo en la isla Española sobre tres cuentos [millares, millones] de ánimas que vimos, no hay hoy de los naturales Della doscientas personas. La isla de Cuba es cuasi tan luenga como desde Valladolid a Roma: está hoy cuasi toda despoblada. La isla de Sant Juan y la de Jamaica, islas muy grandes y muy felices y graciosas, ambas están asoladas... (MARTÍNEZ-SAN MIGUEL, 2009, p. $184-185)^{5}$.

Vinieron los hombres en tanta flaqueza, que todos los travajos cargavan de las pobres mugeres, ansi en lavarles las ropas, como en curarles, hazerles de comer lo poco que tenian, alimpiarlos, hazer sentinela, rondar los fuegos, armar las ballestas, quando algunas vezes los yndios les venien á dar guerra, hasta cometer á poner fuego en los versos, y á levantar los soldados, los questavan para hello, dar arma por el canpo á bozes, sargentenando y poniendo en orden los soldados; porque en este tiempo, como las mugeres nos sustentamos con poca comida, no aviamos caydo en tanta flaqueza como los hombres (SCOTT, 1999, p. 9) .

\footnotetext{
5 It was upon these gentle lambs, imbued by the Creator with all the qualities we have mentioned, that from the very first day they clapped eyes on them the Spanish fell like ravening wolves upon the fold, or like tigers and savage lions who have not eaten meat for days. The pattern establishes at the outset has remained unchanged to this day, and the Spaniards still do nothing save tear the natives to shreds, murder them and inflict upon them untold misery, suffering and distress, tormenting, harrying and persecuting them mercilessly. We shall in due course describe some of the many ingenious methods of torture they have invented and refined for this purpose, but one can get some idea of the effectiveness of their methods from the figures alone. When the Spanish first journeyed there, the indigenous populations of the island of Hispaniola stood at some three million; today only two hundred survive. The island of $\mathrm{Cuba}$, which extends for a distance almost as great as the separating Valladolid from Rome, is now to all intents and purposes uninhabited; and two other large, beautiful and fertile islands, Puerto Rico and Jamaica, have been similarly devastated

6 The men became so weak that all the work fell on the poor women: from washing their clothe to caring for the sick, making them eat the little they had, cleaning them, staing guard, tehnding th watch-fires, arming hte crossbows when sometime there were Indian attacks and even firing the culverins; we sound the alarm to the soliders with loud voices, we drilled them and put them in order, for at that time we women could get by with less food and had not fallen into such a state of weakness as the men.
} 
In the description of Las Casas there is a clear goal of describing flora and fauna and hospitality of the natives juxtaposed with the savagery of the Spaniards as metaphorical wolves by the repetition using lists of adjectives, hyperbole and verbs (MARTÍNEZ-SAN MIGUEL, 2009, p. 185). The same holds true in an almost identical pattern in Guevara's text as she describes the laborious effort the women assumed in both their tasks and the risks taken to their personal health by aiding their male comrades. From these two examples it is clear that Guevara's text fits with the "minor" literature model that MartínezSan Miguel presents when analyzing Las Casas in that there is clear deterritorialization of language as seen in the two aforementioned examples, an individual dimension as she is the sole writer of the letter, and a collective enunciation because Guevara implicates in her writing not just her husband but strategically employs the other colonial women and also men that were writing the same type of letters, reaching out to the Spanish authority back in the peninsula.

Guevara's use of the third person, by speaking of ciertas mugeres right up until the end of her letter in which she shifts to the first person in order to ask for the repartimiento that she herself merits for her efforts, has previously been commented on (TIEFFEMBERG, 1989, p. 278$300)$. What should we as readers make of her shift in narrative voice? Who is Isabel de Guevara speaking for? The question of speaking for others - speaking for on behalf of, and about others - is a politically important one for feminist academic and activists and presents a host of problems traversing power, privilege, and oppression in discursive and material arenas.

Linda Alcoff's text The Question of Speaking for Others posits "whether all instance of speaking for others should be condemned and, if not, how we can justify a position that would repudiate some speakers while accepting others" (ALCOFF, 1992-3, p.5). She frames the "problem of speaking for others" in terms of representation in which all acts of speaking (speaking for/about myself/others) involve constructing subject positions through one's own situated interpretation. These positions have both material origins and consequences that are negotiated through discourse, location, and power. Adopting what Foucault calls "rituals of speaking", Alcoff argues that one's social position is deeply intertwined with the discursive practices of writing/ speaking or the text/utterance. Rituals of speaking occur within a discursive context that refers to other utterances in a way that is always political. The meanings that these utterances take on are subject to 
change as the fluidity of context and historical moment is in continual flux. With this in mind, it becomes important to politically contextualize "truth" claims made by a speaking subject in order to authorize or deauthorize his or her speech.

Alcoff's theorizations prove useful when assessing Guevara's text in a large corpus of "minor" literature in the Americas. Recalling the minor literary strategies in a colonial context it appears that Guevara directly employs a "ritual of speaking" for others that Alcoff articulates; a speaking with and to that challenges the discursive structure of speaking by which speaking/knowing subjects challenge their status as objects of knowledge. By pronouncing the injustices done in the Americas, bearing witness to a unique experience of personal hardship experienced by a collective group of women adds the "with" component and her address to the Princess on some level allows a speaking "to" the closest epistemologically similar reality back in Spain. However, this last point of addressing the Princess seems to be overvalued by some critics.

The question of sisterhood highlights a feminist epistemology grounded in a "woman's consciousness" or that the common bond of womanhood would sustain her demands. It is our contention that we learn more about Guevara and her use of minor literature, rhetoric, and an intentionality on her part to establish a sisterly or womanly bond. The Princess's access to knowledge about life in the colonies was not a first-hand witnessing and her hierarchal status as royalty would not provide access to a reality of "hard work" and conceptualization of the danger women faced tending to wounded men. From 1554 to 1559 Princess Juana assumed the role of governess of Spanish overseas territories and upon review of various critics, inferences are made to suggest that Isabel de Guevara actively sought out Princess Juana and thus bypassing the King completely. This is not entirely true, as Juana was the appointed monarch in charge of governing all overseas territories while her father was out of the country (MARRERO-FENTE, 2003, p. 13-16). In fact the significance of the text is better addressed by, "precisamente la participación de las mujeres en la empresa colonial - que la carta destaca - lo que distingue a esta relación de otras crónicas americanas". (MARRERO-FENTE, 2003, p. 9)7 7

Throughout the last several decades the text has been analyzed through epistemological and legal frameworks but in any case

Precisely the participation of women in the colonial enterprise - which the letter emphasizes - is what distinguishes this relationship from other American chronicles. 
comprehensively valued for its completeness and the clear agency present in the character of her writing. While is true, that Isabel de Guevara's letter is in part about putting into question tenets of gender roles, what does the letter offer in the way of a colonial reality and writing characterized by a colonial subjectivity? Is it unlike that present inside the Spain of that time? To be clear, there is no doubt that Guevara's text demands indemnification but socio-historically contextualized, these claims were not unheard of for the time period. Many women in the colonies worked actively in trade, mining, or even administrative positions. Undoubtedly, Spanish and Creole immigrants were participants in the local economy within colonial hierarchical constraints. In Isabel de Guevara's case, action is taken under the administration of Domingo Martínez de Irala. She does so due to Irala's direct distribution of encomiendas and native slaves for which she received nothing. It is clear that the letter problematizes the spatial and social control of the injustices done to her by the patriarchal order. On one level is the testimony of a mobility and participation in various activities that do not correspond to what could be called "feminine nature" and clearly those women were not limited to the realm of domesticity. The second corresponds to the field of rhetoric. The use of the word to address the Princess by Guevara is at that time an act of transgression spatially, to break with the silence they were originally destined to fulfill. In her letter, modes of discourse construction reveal an assured subject who is, at the same time, an agent that replicates and criticizes colonial structure, which is mediated by distance (SILVA, 2011, p. 20-21). Evidently, women's roles back in the peninsula were far more greatly controlled, suppressed, and limited. In fact, it is in her marginalization and peripheral positioning both spatially and physically from a life in Spain that affords her the opportunity to make such bold demands.

It is clear that meanings emerge in specific historical context and we must assess the discursive event (speaking, listeners, words, environment, context of reception, etc.) as a whole. Although our ability to predict the probable effects or know the actual effects are limited, we can increase our ability by engaging in dialogue with the listeners and learning as much as we can about the context of reception. Furthermore, although we can contest the privileging of the "original" source/author since texts are re-interpreted, we can still connect a source to effect. Lastly, a genealogical analysis of the source can be productive for underling an effect otherwise absent from critical critique. Isabel de Guevara's text is a clear representation of feminine agency but once 
incorporated in a larger corpus of colonial "minor" literature, the full effect of her colonial and female subjectivity is realized.

\section{References}

ALCOFF, Linda. The Problem of Speaking For Others. Culture Critique, 20, 1992-3.

ALZATE, Carolina. Isabel de Guevara y Cristóbal Colón: Demandas de la Conquista. Cuadernos de Literatura, 5/9, 1999.

COUCHMAN, Jane; CRABB, Ann. Women's letters across Europe, 1400-1700: form and persuasion. Aldershot: Ashgate, 2005.

COLUMBUS, Christopher. "Journal of the First Voyage of Columbus," in Julius E. Olson and Edward Gaylord Bourne (Eds.). The Northmen, Columbus and Cabot, 985-1503, Original Narratives of Early American History. New York: Charles Scribner's Sons, 1906.

COSTAMAGNA, Giorgio. Ilnotaio a Genovatraprestigio e potere. Roma: Consiglio nazionale del notariato, 1970.

CHEREWATUK, Karen; WIETHAUS, Ulrike. Dear Sister: medieval women and the epistolary genre. Philadelphia: University of Pennsylvania Press, 1993.

DAYBELL, James. Early modern women's letter writing, 1450-1700. Houndmills, Basingstoke, Hampshire: Palgrave, 2001.

DOTY, William G. Letters in primitive Christianity. Philadelphia: Fortress Press, 1973.

FOUCAULT, Michel. La verdad y las formas jurídicas. Barcelona: Gedisa, 1992.

GOLDSMITH, Elizabeth C. Writing the female voice: essays on epistolary literature. Boston: Northeastern University Press, 1989.

KRISTELLER, Paul Oskar. "Rhetoric in Medieval and Renaissance Culture". In: James Murphy (Ed.). Renaissance Eloquence: Studies in the Theory and Practice of Renaissance Rhetoric. Berkeley: University of California Press, 1983.

LANGA, Mar del. "Mujeres en la expedición de Pedro de Mendoza: cartas, crónicas y novelas; verdades, mentiras, ficciones y silencios". América sin nombre, 15, 2010.

LOCKHART, James, and Enrique Otte. Letters and people of the Spanish Indies, sixteenth century. Cambridge: Cambridge University Press, 1976.

LOPRETO, Gladis. La carta de Isabel de Guevara. Asunción: Instituto Histórico de la Municipalidad, 1987.

MARRERO-FENTE, Raúl. Al margen de la tradición. Relaciones entre la literatura colonial y peninsular en los siglo XV, XVI y XVII. Madrid: Fundamentos, 1999.

. "De retórica y derechos: Estrategias de la reclamación en la carta de Isabel de Guevara", Hispania: A Journal Devoted to the Teaching of Spanish and Portuguese, 79/1, 1996.

. "Carta de Isabel de Guevara a la princesa-gobernadora doña Juana”. In: Luisa Campuzano and Catharina Vallejo (Eds.). Yo con mi viveza: Textos de conquistadoras, monjas, brujas, poetas y otras mujeres de la colonia. Havana: Casa de las Américas, 2003. 
MARTÍNEZ-SAN MIGUEL, Yolanda. Colonial Writings as Minority Discourse? In: José Antonio Mazzotti and Ralph Bauer (Eds.). Creole Subjects in the Colonial Americas: Empires, Texts, Identities. Chapel Hill: University of North Carolina, 2009.

MURPHY, James. Medieval rhetoric; a select bibliography. Toronto: University of Toronto Press, 1989.

OTS Y CAPDEQUÍ, José María. Historia del derechoespañol en América y delderecho indiano. Madrid: Aguilar, 1969.

QUISPE-AGNOLI, Rocío. "Discursos coloniales escritos y agencia femenina: La 'Carta a la Princesa Juana' de Isabel de Guevara", CIEHL: Cuadernos Internacional de Estudios Humanísticos y Literatura, 5 (2005-2006) p. 81-91.

RESTALL, Matthew. Seven myths of the Spanish conquest. New York: Oxford University Press, 2003.

SCOTT, Nina M. Madres Del Verbo/Mothers of the Word: Early Spanish-American Women Writers: A Bilingual Anthology. Albuquerque: University of New Mexico, 1999.

SEIGEL, Jerrold E. Rhetoric and philosophy in Renaissance humanism: the union of eloquence and wisdom, Petrarch to Valla. Princeton, N.J.: Princeton University Press, 1968.

SILVA, Yamile. Práctica sescriturales femeninas: Espacialidad e identidad en epístolas en la Colonia (Río de La Plata, Siglos XVI-XVII). Diss. University of Massachusetts, Amherst, 2011.

SZURMUK, Monica. Mujeres en Viaje. Buenos Aires: Alfaguara, 2000.

TIEFFEMBERG, Silvia. Isabel de Guevara o la construcción del yo femenino. Filología, 24/1-2, 1989.

ZARAGOZA, Justo. Cartas de Indias. Madrid: Ediciones Atlas, 1974.

ZORRAQUÍN BECÚ, Ricardo. Estudios de historia del derecho. Buenos Aires: Abeledo-Perrot, 1988.

Received: November 13, 2015

Accepted: February 02, 2016

\section{Authors/Autores:}

RAÚl MARRERO-FENTE <rmarrero@umn.edu>

- Professor of Spanish and Law at the University of Minnesota. His research focuses on colonial Latin America, early modern studies, and global Hispanophone studies. He is the author of several books, among them, Trayectorias globales: estudios coloniales en el mundo hispánico (Iberoamericana/Vervuert, 2013), and co-editor of Coloniality, Religion and the Law in the Early Iberian World (Vanderbilt University Press, 2014).

- Professor de Espanhol e Lei na Universidade de Minnesota. Sua pesquisa foca na América Latina colonial, estudos sobre o início da era moderna e estudos globais hispanófonos. Ele é o autor de diversos livros, entre eles, Trayectorias globales: estudios coloniales en el mundo hispánico (Iberoamericana/Vervuert, 2013) e co-editor de Coloniality, Religion and the Law in the Early Iberian World (Vanderbilt University Press, 2014).

SCOTT EHRENBURG <ehren020@umn.edu>

- Ph.D. Candidate in Spanish Literature at the University of Minnesota. His research interests include transatlantic studies, contemporary Iberian literatures and cultures, and feminist and critical sexuality studies.

- Doutorando em Literatura espanhola na Universidade de Minnesota. Seus interesses de pesquisa incluem estudos transatlânticos, literaturas e culturas contemporâneas Ibéricas e estudos críticos e feministas da sexualidade. 